\title{
Formation of Biofilm by Staphylococcus Spp. in Bovine Mastitis Staphylococci Biofilm in Bovine Mastitis
}

\author{
Ricardo Antonio Pilegi Sfaciotte ${ }^{1 *}$, Fernanda Danielle Melo ${ }^{1}$, Sheila Rezler Wosiacki ${ }^{2}$ and Sandra Maria \\ Ferraz $^{1}$ \\ ${ }^{1}$ Center for Animal Microbiological Diagnosis, State University of Santa Catarina, Brazil \\ ${ }^{2}$ State University of Maringá, Umuarama campus, Brazil
}

Submission: February 15, 2019; Published: February 25, 2019

*Corresponding author: Ricardo Antonio Pilegi Sfaciotte, Center for Animal Microbiological Diagnosis, State University of Santa Catarina, Agroveterinary Science Center, Avenida Luiz de Camões, no 2090, 88520-000, Lages, Brazil

\begin{abstract}
Therefore, the objective of this review is to present the main problems caused by the formation of Staphylococci biofilm isolates from cows with mastitis and the difficulty of treatment of these animals. Biofilms comprise microcolonies of microorganisms adhered to the surface and surrounded by a polymer matrix of their own synthesis, consisting of polysaccharides, proteins and nucleic acids, called exopolysaccharides (EPS). The importance of the icaABCD operon for biofilm formation has been established as an enhanced virulence of the Staphylococcus. However, in some strains of Staphylococcus aureus and S. epidermidis, the expression of biofilm occurs independently of the expression of this operon, since the production of a wide variety of adhesion proteins allows the establishment of biofilm. Originally considered an important hygiene risk in the food industry, biofilms also cause significant economic losses due to technical failures and corrosion of surfaces and equipment and contribute to the increased risk of infection in the medical field, mainly due to contamination and dissemination through medical devices, such as catheters, which could harm human health. Besides antimicrobial resistance, biofilm formation confers resistance to the action of physical and chemical agents, as well as disinfectants, and products used in the hygiene process, pre and post dipping at the time of milking.

Keywords: Biofilm; Resistance; Staphylococccus mastitis
\end{abstract}

\section{Introduction}

Biofilms comprise microcolonies of microorganisms adhered to the surface and surrounded by a polymer matrix of their own synthesis, consisting of polysaccharides, proteins and nucleic acids, called exopolysaccharides (EPS). Biofilms may be homogeneous, consisting of only one species (rare), or heterogeneous, composed of several bacterial species or even fungi, yeasts, algae and other unicellular organisms [1]. In heterogeneous biofilms, the metabolic by products of a microorganism may favor the growth of another species, as well as, the adhesion of a species can provide binding and binding sites for other bacterial species [2]. The protein matrix of biofilms formed by Staphylococcus aureus and S. epidermidis is composed of polysaccharide intercellular adhesin (PIA) or polymeric N-acetyl-glucosamine (PNAG) [1,3]. The icaABCD operon genes encode the PIA synthesis and deacetylation $[4,5]$. The importance of the icaABCD operon for biofilm formation has been established as an enhanced virulence of the Staphylococcus. However, in some strains of Staphylococcus aureus and S. epidermidis, the expression of biofilm occurs independently of the expression of this operon, since the production of a wide variety of adhesion proteins allows the establishment of biofilm $[6,7]$. Therefore, the objective of this review is to present the main problems caused by the formation of Staphylococci biofilm isolates from cows with mastitis and the difficulty of treatment of these animals.

\section{Staphylococci Biofilm Problem}

The formation of biofilms according to Notermans, Dormans \& Mead [8] occurs in three phases: adsorption or adhesion, consolidation and colonization. In the first phase of adhesion, physical forces allow the adhesion of bacterial cells to almost all types of surfaces, but this adhesion is reversible. In the next stage of consolidation, the bacteria begin to produce the matrix of extracellular substances, the EPS, causing an irreversible adhesion. In the third and last stage of colonization, the EPS layer allows the establishment and multiplication of bacterial cells on the surface, giving rise to the biofilm itself. As soon as its structure is consoli- 
dated, some cells are released from the biofilm being released in the medium, allowing the bacterial spread $[9,10]$.

The mechanisms involved in the expression of binding proteins and the expression of EPS, as well as their participation in the formation of Staphylococcus biofilms, are not fully elucidated. Therefore, several studies have been carried out to better understand these mechanisms [11]. Maintaining the activities of a biofilm is deeply related to quorum-sensing mechanisms. Through the production and release of signaling and self-inducing molecules, which concentration increases as a function of bacterial population density. Bacteria can perceive a certain threshold of stimulation of these auto-inducing molecules, inciting alterations in gene expression and, consequently, in behavior. Thus, bacteria from a biofilm can synchronize their activities by functioning as multicellular organisms [12].

Originally considered an important hygiene risk in the food industry, biofilms also cause significant economic losses due to technical failures and corrosion of surfaces and equipment and contribute to the increased risk of infection in the medical field, mainly due to contamination and dissemination through medical devices, such as catheters, which could harm human health $[3,13]$. Recent research also points to its relationship with various infections in animals, including clinical and subclinical cases of bovine mastitis, spread through fomites, contaminated equipment and by the handlers. The process of infection of the mammary gland by microorganisms of contagious origin, such as species of Staphylococcus, occurs upwardly through the canal of the ceiling and, in view, the potential of them to adhere and to form biofilms remaining in the alveoli, as sources of infection and constant contamination, shows the importance of the correct antisepsis of ceilings, equipment and hands of milkers [14]. Under conditions of anoxia, transcription of the operon ica is increased, and consequently of the production of PIA $[4,15]$. The ability to form biofilms protects microorganisms against attacks of the immune system, dehydration, increase resistance to antimicrobials, propitiating the creation of a microniche itself with increased availability of nutrients and their absorption through the extracellular polysaccharides $[3,6]$.

Simojoki [16] believe that biofilm formation by mastitis-causing Staphylococcus is a means of escaping the immune system of the animals and causing more persistent intramammary infections. In addition, Staphylococcus spp. in biofilms demonstrate high resistance to antimicrobial agents due mainly to the low diffusion of these drugs in the exopolysaccharide matrix, thus compromising the efficacy and success of treatment of animals with mastitis [14]. Some studies have shown that the concentrations of antimicrobials to eliminate bacteria in biofilms can be up to 1000 times greater than those required to eliminate them in their planktonic state $[17,18]$. Resistance mechanisms of biofilms are generally multifactorial and include factors such as low penetration of antimicrobials through the biofilm matrix; slow or absence of growth of the cells that compose the biofilm; presence of heterogeneity of the bacterial population of the biofilm with the presence of different resistance phenotypes; and the presence of "persisters" cells [19], which are found in the structural basis of biofilms where there is little availability of oxygen with a low metabolic rate, guaranteeing their resistance to antimicrobial treatment, since they are generally bacterial growth phase [20].

Besides antimicrobial resistance, biofilm formation confers resistance to the action of physical and chemical agents, as well as disinfectants, and products used in the hygiene process, pre and post dipping at the time of milking [21]. Strategies to avoid biofilm formation include regular disinfection, even during the initial stage of biofilm formation; disinfection of biofilms already formed using aggressive disinfectants; and inhibition of the fixation of microorganisms through the selection of materials that do not promote the establishment of these bacteria [13]. Thus, the use of appropriate products and equipment associated with the correct performance of the pre and post dipping and hygiene of the milking equipment helps to inhibit or reduce the chance of development of biofilm producing bacteria in bovine mastitis.

\section{Conclusion}

Staphylococcus is one of the major microorganisms that cause mastitis. The formation of biofilm by this bacterium makes it even more difficult to treat the animals by reducing the action of antimicrobials in the mammary tissue. Thus, some strategies to treat bovine mastitis are aimed at inhibiting or reducing the chance of developing biofilm-producing bacteria in bovine mastitis.

\section{Conflict of Interest}

It is declared that there is no conflict of interest or other interest of interest.

\section{References}

1. Sauer K, Rickard AH, Davies DG (2007) Biofilms and biocomplexity. Amer Society Microb 2(7): 247-253.

2. Dunne WM (2002) Bacterial adhesion: seen any good biofilms lately? Clin Microbiol Rev 15(2): 155-166.

3. Götz F (2002) Staphylococcus and biofilms. Mol Microb 43(6): 13671378.

4. Atshan SS, Shamsudin MN, Thian Lung LT, Seakawi Z, Ghaznavi-Rad E, et al. (2012) Comparative Characterization of Genotypically Different Clones of MRSA in the Production of Biofilms. J Biomed Biotechnol 2012: 417247.

5. Cue D, Lei MG, Lee CY (2012) Genetic regulation of the intercellular adhesion locus in staphylococci. Front Cell Infect Microbiol 2(38): 23061050 .

6. O'Gara JP (2007) Ica and beyond: biofilm mechanisms and regulation in Staphylococcus epidermidis and Staphylococcus aureus. FEMS Microbiol Lett 270(2): 179-188.

7. Lasa I, Penadés JR (2006) Bap: A family of surface proteins involved in biofilm formation. Res. Microbiol 157(2): 99-107.

8. Notermans S, Dormans JAMA, Mead GC (1991) Contribution of surface attachment to the establishment of microorganisms in food processing plants: A review. Biofouling 5: 21-36. 
9. Vasudevan P, Nair MKM, Annamalai T, Venkitanarayanan KS (2003) Phenotypic and Genotypic characterization of bovine mastitis isolates of Staphylococcus aureus for biofilm formation. Vet Microb 92: 179185.

10. Gilbert P, McBain AJ, Rickard AH (2003) Formation of microbial biofilm in hygienic situations: a problem of control. Int Biodeterior. Biodegrad 51(4): 245-248

11. Atkin KE, Macdonald SJ, Brentnall AS, Potts JR, Thomas GH (2014) A different path: Revealing the function of staphylococcal proteins in biofilm formation. FEBS Lett 588: 1869-1872.

12. Water CM, Bassler BL (2005) Quorum sensing: cell-to-cell communication in bactéria. Annu Rev Cell Dev Biol 21: 319-346.

13. Meyer B (2003) Approaches to prevention, removal and killing of biofilms. Int Biodeterior Biodegradation 51: 249-253.

14. Melo PC, Ferreira LM, Nader-Filho A, Zafalon LF, Vicente HIG (2012) Análise fenotípica e molecular da produção de biofilmes por estirpes de Staphylococcus aureus isoladas de casos de mastite subclínica bovina. Biosci J 28(1): 94-99.

15. Lin MH, Shu JC, Huag HY, Cheng YC (2012) Involvement of iron in biofilm formation by Staphylococcus aureus. Plosone 7(3): 34388.

16. Simojoki H, Hyvönen P, Plumed Ferrer C, Taponen S, Pyörälä S (2012) Is the biofilm formation and slime producing ability of coagulase negative staphylococci associated with the persistence and severity of intramammary infection. Vet Microbiol 158: 344-352.

17. Van Praagh ADG, Li T, Zhang S, Arya A, Chen L, et al. (2011) Daptomycin antibiotic lock therapy in a rat model of staphylococcal central venous catheter biofilm infections. Antimicrob Agents Chemother 55(9): 4081-4089.

18. Hook AL, Chang CY, Yang J, Luckett J, Cockayne A, et al. (2012) Combinatorial discovery of polymers resistant to bacterial attachment. Nat Biotech 30(9): 868-875.

19. Cafiso V, Bertuccio T, Spina D, Purrello S, Stefani S (2010) Tigecycline inhibition of a mature biofilm in clinical isolates of Staphylococcus aureus: comparison with other drugs. FEMS Immunol Med Microbiol 59(3): 466-469.

20. Stewart PS (2002) Mechanisms of antibiotic resistance in bacterial biofilms. Int J Med Microbiol 292(2): 107-113.

21. Santos SS (2009) Investigação da presença e da formação de biofilmes por estafilococos em micro-usina de beneficiamento de leite. $57 \mathrm{f}$. Dissertação (Mestre em Medicina Veterinária - Medicina Veterinária Preventiva) - Universidade Estadual Paulista "Júlio de Mesquita Filho" - Faculdade de Ciências Agrárias e Veterinárias. Jaboticabal-São Paulo.

Your next submission with Juniper Publishers
will reach you the below assets
- Quality Editorial service
- Swift Peer Review
- Reprints availability
- E-prints Service
- Manuscript Podcast for convenient understanding
- Global attainment for your research
- Manuscript accessibility in different formats
( Pdf, E-pub, Full Text, Audio)
- Unceasing customer service
Track the below URL for one-step submission
https://juniperpublishers.com/online-submission.php

